\title{
Comparative study among clinical and commensal isolates of Enterococcus faecalis for presence of esp gene and biofilm production
}

\author{
Giridhara P M Upadhyaya ${ }^{1}$, Umapathy B Lingadevaru², Ravikumar K Lingegowda ${ }^{1}$ \\ ${ }^{1}$ Department of Microbiology, Kempegowda Institute of Medical Sciences, Banashankari II stage, Bangalore- \\ 560070, India \\ ${ }^{2}$ Department of Microbiology, ESI-PGIMSR, Rajajinagar, Bangalore-560010, India
}

\begin{abstract}
Introduction: Because of increasing difficulty in treating enterococcal infections, effort is being devoted to understanding factors that are responsible for causing nosocomial infection, with a focus toward targeting these factors with new therapeutics. Evidence has emerged that the esp gene mediates biofilm formation in vitro, which helps the organism colonize and cause infection.

Methodology: This study was conducted over a four-year period in a tertiary-care hospital. There were 200 clinical pathogenic strains isolated from nosocomial infections and 100 commensals from stool specimens of healthy individuals. The study compared the production of biofilm and detection of the esp gene among clinical and commensal isolates.

Results: Among 200 clinical isolates of Enterococcus faecalis 65 (32.5\%) isolates were positive for biofilm production and 60 (30\%) for the esp gene by PCR. Among 100 commensal isolates, $16 \quad(8 \%)$ and $14(7 \%)$ were positive for biofilm formation and the esp gene, respectively. Five clinical and two commensal isolates produced biofilm without any amplification of the esp gene.

Conclusion: The study shows a significant difference in production of biofilm and presence of the esp gene between clinical and commensal isolates $(P<0.002)$. Therefore, it can be concluded that biofilm production has an important role in causing nosocomial infection. Although detection of the esp gene correlates with biofilm production, it may not be the only factor determining the formation of biofilm since few isolates produced biofilm without the esp gene. Strains isolated from indwelling medical devices showed high production of biofilm and esp gene.
\end{abstract}

Key words: Enterococcus; nosocomial; virulence; biofilm; esp gene

$J$ Infect Dev Ctries 2011; 5(5):365-369.

(Received:12 July 2010 - Accepted: 05 November 2010)

Copyright (C) 2011 Upadhyaya et al. This is an open-access article distributed under the Creative Commons Attribution License, which permits unrestricted use, distribution, and reproduction in any medium, provided the original work is properly cited.

\section{Introduction}

Enterococci are commensal organisms of gastrointestinal (GI) tracts. While more than 100 years ago they were recognized as being capable of causing serious infection in humans [1], over the past three decades enterococcal strains have emerged as the leading organisms causing nosocomial infections. They are resistant to virtually all antibiotics, including vancomycin and linezolid, the last resort of treatment for Gram-positive infections. Enterococci occur in the colon of nearly all humans, where they can be found in numbers as high as $10^{8}$ colonyforming units (CFU) per gram of faeces [2,3]. This is evidence that enterococci have successfully evolved traits that enable stable colonization of this highly competitive niche. Enterococcus faecalis currently accounts for $65-80 \%$ of all enterococcal nosocomial infections $[2,4]$.
It is well-known that virulence of an organism is regulated by virulence coding genes present in special regions of the genome which are termed pathogenicity islands (PAI). The enterococcal PAI was first identified in the genome of a multidrugresistant strain of E. faecalis [MMH594] that had caused an outbreak of nosocomial infection in the 1980s [5].

Direct experimental evidence suggests that the Esp protein acts as an adhesin in the colonization of the urinary tract [6]. Evidence has emerged that the esp gene mediates biofilm formation in vitro [7]. Shankar et al. (2001) found that $93.5 \%$ of esp geneharboring $E$. faecalis strains formed biofilm on polystyrene, whereas none of the esp-deficient strains did [06]. The esp gene has been detected in close association with the cytolysin operon on the chromosome of the E. faecalis ward outbreak strain 
Table 1. Demographic and clinical characteristics of 200 patients with nosocomial infection due to $E$. faecalis

\begin{tabular}{|l|c|}
\hline Characteristics & Number of cases (\%) \\
\hline Age, years (range) & $16-66$ \\
\hline Male / female & $131 / 69$ \\
\hline Post operative wound infection & $125(62.5)$ \\
\hline Endotracheal tube infection & $23(11.5)$ \\
\hline Diabetic foot infection & $20(10)$ \\
\hline Urinary tract infection & $15(7.5)$ \\
\hline Infected compound fracture & $7(3.5)$ \\
\hline Septicemia catheter tip & $5(2.5)$ \\
\hline Burn cases & $2(1.5)$ \\
\hline $\begin{array}{l}\text { Umbilical } \\
\text { infection }\end{array}$ \\
\hline
\end{tabular}

MMH594 [8]. The cytolysin operon and the esp gene are found within a region that appears to be subjected to rearrangement. The association of adhesion with toxins has been recognized among isolates of $E$. coli from urinary tract infections [9-11]. It can be hypothesized that on the basis of the proximity of the esp gene to the cytolysin operon within this region and its role in generating microenvironments where a quorum of bacteria would accumulate (e.g., biofilms), the esp gene may function synergistically with the cytolysin in a manner analogous to the previously documented synergy between aggregation substance and cytolysin in endocarditis.

\section{Methodology}

This study was conducted from July 2004 to July 2009. Three-hundred and ninetyseven Enterococcus spp were isolated from different clinical nosocomial samples. Two hundred isolates were confirmed as $E$. faecalis by biochemical reactions [12]. The demographic distribution of the clinical isolates is mentioned in Table 1. One hundred commensal isolates of E. faecalis were isolated from stool samples.

For investigation of biofilm production, bacterial strains were grown in tripticase-soy broth (TSB, from Hi-Media, Mumbai, India) with $0.5 \%$ glucose and incubated at $37^{\circ} \mathrm{C}$ [13]. After overnight incubation, culture was diluted 1:40 in fresh TSB- $0.5 \%$ glucose. Two hundred microlitres of the diluted solution was added to wells of a flat-bottomed polystyrene microtitre plate and incubated for 48 hours at $37^{\circ} \mathrm{C}$. Wells were gently washed with distilled water and the plate inverted and dried at room temperature for one hour. The adherent biofilm was stained with $0.1 \%$ saffranin dye and incubated for 20 minutes at room temperature. Absorbance of the biofilm on the bottom surface of each well of the dried plates was determined at $490 \mathrm{~nm}$ in an ELISA reader (Tecan, Männedorf, Switzerland). The test was conducted in triplicate for concurrence. Biofilm producing esp gene negative $E$. faecalis OG1RF was taken as the positive control. The mean optical density (OD) value of the positive control was taken as the reference value to be compared against. Values above 0.2 were considered as high biofilm producers; values below 0.081 were categorized into low or nonbiofilm producers. OD values above the reference value but within 0.081 and 0.2 were taken as moderate biofilm producers.

All the clinical and commensal isolates were tested for the presence of the esp gene by PCR. DNA extraction was performed by phenol-chloroform extraction. PCR amplification of the esp gene was performed using primers esp $11 \quad\left(5^{\prime}\right.$ TTGCTAATGCTAGTCCACGACC-3') and esp 12 (5'-GCGTCAACACTTGCATTGCCGAA-3'),

corresponding to nucleotide positions 1217-1238 and 2149-2171, respectively, within the N-terminal region of the esp gene [14]. The PCR reaction mixture consisted of $250 \mathrm{ng}$ of DNA sample; $0.2 \mu \mathrm{L}$ each of dATP (2'-deoxyadenosine $5^{\prime}$-triphosphate), dCTP (2'-deoxycytosine 5'-triphosphate), dGTP (2'deoxyguanosine $5^{\prime}$-triphosphate), and dTTP (2'deoxythymidine 5'-triphosphate); $2.5 \mathrm{mM} \mathrm{MgCl}_{2}$; and $2.5 \mathrm{U}$ of AmpliTaq DNA polymerase in $1 \mathrm{X}$ reaction buffer (Bangalore Genei, Bangalore, India). The samples underwent initial denaturation at $95^{\circ} \mathrm{C}$ for two minutes then were subjected to 40 cycles of denaturation $\left(94^{\circ} \mathrm{C}\right.$ for 45 seconds), annealing $\left(63^{\circ} \mathrm{C}\right.$ for 45 seconds) and extension $\left(72^{\circ} \mathrm{C}\right.$ for 1 minute). The amplification mixture was subjected to electrophoresis. The reaction products were visualized by ethidium bromide staining. Reference isolates of E. faecalis MMH594 (which carried the esp gene) and OG1RF (which did not carry the esp gene) were used as positive and negative controls, respectively. The distributions of these two virulence factors among the different clinical specimens were also verified.

\section{Statistical analysis}

Statistical analysis of the data was produced with SPSS software (IBM, Rochester, NY version 15). Chi-square test and $P$ values were calculated, and a significant difference was noted among clinical and commensal isolates with respect to production of biofilm and esp production. 
Table 2. High, moderate and non-biofilm producers among clinical and commensal isolates

\begin{tabular}{|c|c|c|}
\hline Biofilm formation $\mathbf{O D}_{\mathbf{4 9 0} \mathbf{~ n m}}$ & $\begin{array}{c}\text { Clinical isolates } \\
(\mathbf{n}=\mathbf{2 0 0})\end{array}$ & $\begin{array}{c}\text { Commersal isolates } \\
(\mathbf{n}=\mathbf{1 0 0})\end{array}$ \\
\hline High $(>0.20)$ & $23(11.5 \%)$ & $4(4.0 \%)$ \\
\hline Moderate $(>0.081$ and $<0.20)$ & $42(21.0 \%)$ & $12(12.0 \%)$ \\
\hline $\begin{array}{c}\text { Weak/non-biofilm producers }(< \\
0.081)\end{array}$ & $135(67.5 \%)$ & $84(84.0 \%)$ \\
\hline
\end{tabular}

Chi-square test. $(\mathrm{X}$-squared $=9.653, \mathrm{df}=2, P$ value $=0.008015)$

Table 3. Comparison among clinical and commensal isolates for production of biofilm and esp gene $(P$ value $>0.05)$

\begin{tabular}{|c|c|c|}
\hline Factor & $\begin{array}{c}\text { Clinical isolates } \\
(\mathbf{n}=\mathbf{2 0 0})\end{array}$ & $\begin{array}{c}\text { Commensal isolates } \\
(\mathbf{n}=\mathbf{1 0 0})\end{array}$ \\
\hline Biofilm & $65(35.0 \%)$ & $16(8.0 \%)$ \\
\hline$E s p$ gene & $60(30.0 \%)$ & $14(7.0 \%)$ \\
\hline
\end{tabular}

\section{Results}

Production of biofilm among clinical and commensal isolates

Out of the 200 clinical isolates, 23 samples showed an OD value greater than 0.2, suggesting high biofilm producing strains; 42 samples showed an OD greater than the positive control but below 0.2, suggesting moderate biofilm-producing strains. Of the 100 commensal isolates, only four samples showed high production of biofilm, and 12 samples showed moderate production of biofilm as shown in Table 2.

Presence of esp gene among clinical and commensal isolates

Analysis for the presence of the esp gene in clinical isolates and commensals found $60(30 \%)$ positive and $14(14 \%)$ positive, respectively. Statistical analysis provided an $\mathrm{X}$-squared value of 9.1844 and a significant $P$ value $(P=0.002441)$

Further correlation between biofilm formation and presence of the esp gene was observed in the majority of clinical isolates as shown in Table 3, however a comparative study of biofilm production and presence of the esp gene showed that there were five clinical isolates and two commensal isolates that produced biofilm but were negative for esp gene.

Further analysis of clinical isolates revealed that $21.6 \%$ and $19.2 \%$ of strains isolated from postoperative wounds contained biofilm-formers and were positive for esp gene, respectively. In samples from cases of endotracheal tube infection, urinary tract infection, and umbilical catheter tip infection, $60.9 \%, 86.7 \%$ and $100 \%$ isolates showed biofilm production and $56.2 \%, 80.0 \%$ and $100 \%$ were found positive for the esp gene, respectively, as shown in Table 4.

\section{Discussion}

This study shows a significant presence of biofilm formation and the esp gene in nosocomial infections. It is evident from the study that biofilm formation is important in bacterial pathogenesis. Biofilms play a significant role in colonization during infection, providing an opportunity for the bacteria to develop drug resistance. Biofilm forming bacteria are encased in a well-hydrated matrix composed of secreted exopolymeric substances, proteins and nucleic acids from dead-lysed cells that affords protection against host immune clearance and antibiotic therapy [15]. Besides tissue epithelia, bacterial biofilms can also develop on body implant devices [16]. It is conceivable that the increasing use of antibiotics and implant devices in hospitals contribute to the enrichment of traits that promote biofilm development in clinical pathogens [16-18]. Similarly, esp gene presence showed a marked difference between clinical and commensal isolates. There were five clinical isolates and two commensal isolates that produced biofilm independent of the esp gene. Another study has also shown such strains [19]. There was no significant difference among the clinical and commensal isolates with respect to absence of the esp gene $(\mathrm{P}>0.05)$. The results 
Table 4. Combarison between biofilm production and esp gene among different clinical specimens

\begin{tabular}{|l|c|c|}
\hline Clinical samples & $\begin{array}{c}\text { Biofilm formation } \\
(\mathbf{\%})\end{array}$ & $\begin{array}{c}\text { Presence of esp gene } \\
\mathbf{( \% )}\end{array}$ \\
\hline Postoperative wound infection $(\mathrm{n}=125)$ & $27(21.6)$ & $24(19.2)$ \\
\hline Endotracheal tube infection $(\mathrm{n}=23)$ & $14(60.86)$ & $13(56.2)$ \\
\hline Diabetic foot infection $(\mathrm{n}=20)$ & $5(25.0)$ & $5(25.0)$ \\
\hline Urinary tract infection $(\mathrm{n}=15)$ & $13(86.66)$ & $12(80.0)$ \\
\hline Infected compound fracture $(\mathrm{n}=7)$ & $2(28.57)$ & $2(28.57)$ \\
\hline Septicaemia $(\mathrm{n}=5)$ & $2(40.0)$ & $2(40.0)$ \\
\hline Burn cases $(\mathrm{n}=3)$ & 0 & 0 \\
\hline Umbilical catheter tip infection $(\mathrm{n}=2)$ & $2(100)$ & $2(100)$ \\
\hline
\end{tabular}

indicate that there may be more than one factor determining the production of biofilms in enterococci. Biofilm formation may be an adaptive response of the organism; therefore, other virulence factors also need to be explored.

Based on the distribution of biofilm production and presence of the esp gene in various clinical specimens, it is observed that the esp gene and biofilm formation are more prevalent in the organisms isolated from endotracheal tubes $(60.8 \%)$, Foley's catheter tips $(86.6 \%)$ and umbilical catheter tips $(100 \%)$. On that basis, we hypothesize that biofilm and the esp gene are important factors responsible for the ability of E. faecalis to colonize and cause nosocomial infections associated with indwelling medical devices. Moreover, strains that did not form biofilm could be converted to a biofilmformer phenotype by transformation to an esp positive strain. An Esp-like protein that occurs in staphylococci was shown to mediate biofilm formation, indicating that this trait is wide-spread among organisms that cause nosocomial infections related to indwelling devices [20-24].

Use of indwelling medical devices such as catheters, mechanical heart valves and prosthetic joints is associated with an increased risk of infection within the blood-stream and urinary tract. Bacteria also exhibit slower growth rates and greater tolerance to antimicrobial agents when growing in a biofilm [21]. The process of biofilm formation is complex and dependent upon multiple factors including properties of the substratum, presence of a conditioning film, hydrodynamics, physical and chemical properties of the liquid in contact with the device surface, and properties of the colonizing microbial cells [22]. Biofilm-associated bacteria may elicit disease processes by detachment of individual cells or aggregates from the device surface, production of endotoxins or providing a niche for the development of antibiotic-resistant organisms [21]. Biofilm-associated organisms also exhibit tolerance to antimicrobial agents [23]. This tolerance makes the treatment of device-associated infections with systemic antimicrobial agents generally ineffective.

A variant of the esp gene was detected in all epidemic vancomycin-resistant $E$. faecium (VRE) in hospitals but not in non-epidemic animal isolates [24]. This observation indicates that the surface protein Esp is associated with enterococcal colonization and spread. Analysis of the mechanism underlying the influence of this surface protein on transmission of enterococci might lead to new ways to prevent colonization and transmission.

As drug resistance is a major problem in enterococci, it is important to prevent the colonization of the organism by finding novel methods to prevent biofilm formation. Currently, there is more urgency to define the reservoirs for colonization and the routes of transmission of enterococci since few therapeutic options exist for treatment of VRE infections.

\section{References}

1. MacCallum WG and Hastings TW (1899) A case of acute endocarditis caused by Micrococcus zymogenes with a description of the microorganism. J Exp Med 4: 521-534.

2. Huycke MM, Sahn DF, Gilmore MS (1998) Multi-drug resistant Enterococci: The nature of the problem and an agenda for the future. Emerg Infect Dis 4: 239-249.

3. Noble CJ (1978) Carriage of group D streptococci in the human bowel. J Clin Pathol 31:1182-1186. 
4. Sahm DF (2000) Antimicrobial resistance among Enterococci: A view from US clinical laboratories. First International ASM conference on Enterococci, Banff, Canada.

5. Upadhyaya PG, Ravikumar KL, Umapathy BL (2009) Review of virulence factors of Enterococcus: An emerging nosocomial pathogen. Indian J Med Microbiol 27: 301-305.

6. Shankar N, Lockatell CV, Baghdayan AS, Drachenberg C, Gilmore MS, Johnson DE (2001) Role of Enterococcus faecalis surface protein Esp in the pathogenesis of ascending urinary tract infection. Infect Immun 69: 4366-4372.

7. Toledo-Arana A, Valle J, Solano C, Arrizubieta MJ, Cucarella C, Lamata B, (2001) The enterococcal surface protein, Esp, is involved in the Enterococcus faecalis biofilm formation. Appl Environ Microbiol 67: 4538-4545.

8. Shankar N, Baghdayan AS, Huycke MM, Lindahl G, Gilmore MS (1999) Infection-derived Enterococcus faecalis strains are enriched in esp, a gene encoding a novel surface protein. Infect. Immun 67: 193-200.

9. Blum G, Falbo V, Caprioli A, Hacker J (1995) Gene clusters encoding the cytotoxic necrotizing factor type 1, Prsfimbriae and alpha-hemolysin form the pathogenicity island II of the uropathogenic Escherichia coli strain J96. FEMS Microbiol 126: 189-195.

10. Guyer DM, Kao JS, Mobley HL (1998) Genomic analysis of a pathogenicity island in uropathogenic Escherichia coli CFT073: Distribution of homologous sequences among isolates from patients with pyelonephritis, cystitis, and catheter-associated bacteriuria and from fecal samples. Infect Immun 66: 4411-4417.

11. Hacker J, Kaper JB (2000) Pathogenicity islands and the evolution of microbes. Annu Rev Micrbiol 54: 641-679.

12. Ross PW (2008) Streptococcus and Enterococcus. In Mackie \& McCartney Practical Medical Microbiology Eds. Collee JG, Fraser AG, Marmion BP and Simmons A. London: Churchill Livingstone, pp.263-273.

13. Jayanthi S, Ananthasubramanian N, Appalaraju B (2008) Assessment of pheromone response in biofilm forming clinical isolates of high level gentamicin resistant Enterococcus faecalis. Indian J Med Microbiol 23: 248-251.

14. Vergis EN, Shankar N, Chow JW, Hayden MK, Syndman DR, Zervos, Linden PK, Wagener MM, Muder RR (2002) Association between the presence of Enterococcal virulence factors gelatinase, haemolysin and enterococcal surface protein and mortality among patients with bacteremia due to Enterococcus faecalis. Clin Infect Dis 35: 570-575.

15. Costerton, JW, Stewart PS, Greenberg EP (1999) Bacterial biofilms: a common cause of persistent infections. Science 284: 1318-1322.

16. Costerton JW, Montanaro L, Arciola CR ( 2005) Biofilm in implant infections: its production and regulation. Int J Artif Organs 28: 1062-1068.

17. Gilbert $\mathrm{P}$, Allison DG, McBain AJ (2002) Biofilms in vitro and in vivo: do singular mechanisms imply cross-resistance? Symp Ser Soc Appl Microbiol 92: 98S-110S.

18. Hoyle BD and Costerton JW (1991) Bacterial resistance to antibiotics: the role of biofilms. Prog Drug Res 37: 91-105.

19. Kristich CJ, Li YH, Cvitkovitch DG, Dunny GM (2004) Esp-Independent Biofilm formation by Enterococcus faecalis. J Bacteriol 186: 154-163.

20. Cucarella C, Solano C, Valle J, Amorena B, Lasa I, Penades JR (2001) Bap, a Staphylococcus aureus surface protein involved in biofilm formation. J Bacteriol 183: 2888-2896.

21. Donlan RM and Costerton JW (2002) Biofilms: survival mechanisms of clinically relevant microorganisms. Clin Microbiol Rev 15: 167-193.

22. Donlan RM (2002) Biofilms: microbial life on surfaces. Emer Infect Dis 8: 881-890.

23. Stewart PS, Mukherjee PK, Ghannoum MA (2004) Biofilm antimicrobial resistance. In: Ghannoum M, O’Toole GA (eds) Microbial biofilms. Washington DC: ASM Press, , pp.250-268.

24. Willems RJ, Homan W, Top J, van Santen-Verheuvel M, Tribe D, Manzioros X (2001) Variant esp gene as a marker of a distinct genetic lineage of vancomycin-resistant Enterococcus faecium spreading in hospitals. Lancet 357 : 853-855.

\section{Corresponding author}

Giridhara P M Upadhyaya

Assistant Professor

Department of Microbiology

Kempegowda Institute of Medical Sciences

Banashankari $2^{\text {nd }}$ Stage, Bangalore-560070, India

Phone: 0091-9449831147

Fax: 91-080-26712798

Email:pmgu@rediffmail.com

Conflict of interests: No conflict of interests is declared. 